\title{
Vitamins are more Funky than Casimir thought
}

\section{Simon Spedding}

Nutritional Physiology Research Centre, University of South Australia

\section{EDITORIAL}

Please cite this paper as: Spedding S. Vitamins are more Funky than Casimir thought. AMJ 2013, 6, 2, 104-106. http//dx.doi.org/10.4066/AMJ.2013.1588

Corresponding Author:

Simon Spedding

Nutritional Physiology Research Centre

University of South Australia GPO BOX 2471

Adelaide SA 5001 Australia

Email: spedding@adam.com.au

\section{Introduction}

In 2012 we celebrate the centenary of Dr Casimir Funk's discovery of the 'vitamine'. Funk was the first to suggest the existence of a family of organic substances that are essential for life, which the world now takes for granted. He was thus the godfather of the vitamin movement. Funk conceived the concept of "vital amines"; essential nutrients with a specific action, requiring only minute amount with the power to cure a specific disease. As Casimir ${ }^{1}$ phrased it: "We will speak of beriberi and scurvy vitamine, which means a substance preventing that special disease".

A century later, although we may find limitations in Casimir's theory, this does not detract from his genius, or his influence on medical thinking and his role in founding the vitamin industry.

\section{The Life of Casimir Funk}

The upheaval of two World Wars combined with his Polish Jewish ancestry ${ }^{2}$, resulted in Casimir Funk's career spanning the United States and five different European countries. Funk (1884-1967) was born in Warsaw, the son of a Polish physician $^{3}$. Although his parents aspired for him to become a doctor, Funk instead earned a doctorate of chemistry in Switzerland in 1904. He went on to work in the new field of biochemistry at the Pasteur Institute in Paris, continuing his research in Berlin and London. He was first introduced to the concept that ingestion of polished rice could result in beriberi by Dr. Brandon of Malaya. Funk proceeded to isolate the antineuritic factor of vitamins B1 and B3.
Figure 1: Dr Casimir Funk

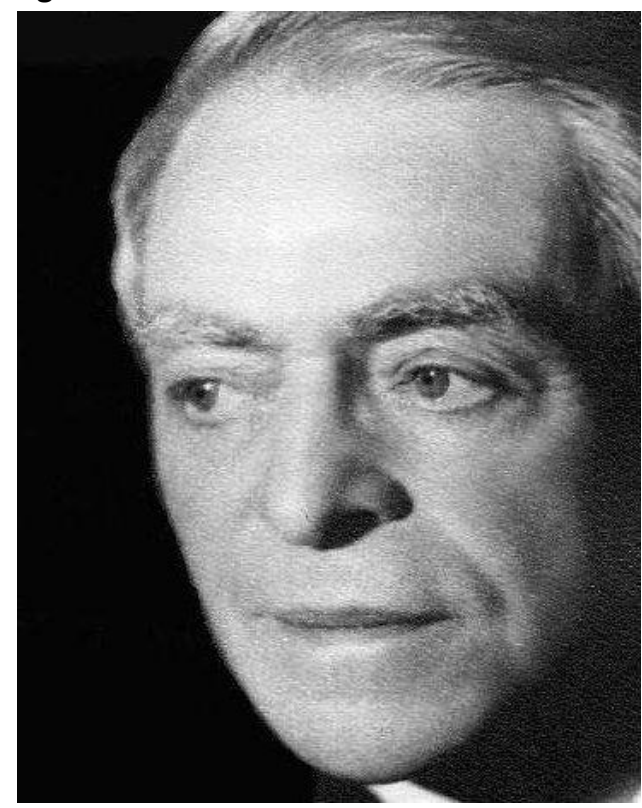

With the outbreak of World War I, Funk immigrated to the United States, where he subsequently developed vitamin formulas including OSCODAL, a vitamin $A$ and $D$ concentrate. The concentrate was the first vitamin preparation to be accepted by the American Medical Association as an ethical product.

Funk returned to Warsaw in 1923, but with the outbreak of World War II, he was forced to flee to the United States. In the United States, he worked with pharmaceutical companies and the US Vitamin Corporation. Funk contributed to many facets of biomedical research and the pharmaceutical industry through 140 technical papers, as well as 30 reviews and articles. ${ }^{3}$

\section{The Genius of Casimir Funk}

With the publication of the paper. ${ }^{1}$ The aetiology of the deficiency diseases in 1912 and the book ${ }^{4}$ Die Vitamine two years later, Funk attracted the interest of the medical and scientific community. This led to the discovery of 13 vitamins within 35 years. These include all the known vitamins: eight forms of vitamin $B$; vitamin $C$; and the four fat-soluble vitamins $A, D, E$ and $K$. This year, the US Congress celebrated Funk's accomplishments by officially honouring the 100th anniversary of his discovery of the vitamin. $^{5}$ 
Figure 2: A bottle of the original vitamins invented by Casimir Funk. The name OSCODAL was derived from OSbone CODA-covitamins $D$ and $A$, L-lozenge

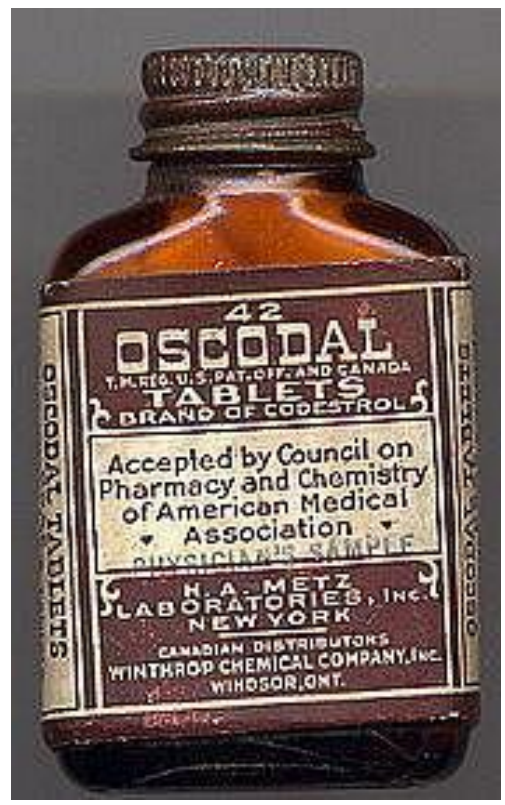

\section{The legacy of Casimir Funk}

Funk's concept of a group of 'life-giving amines' was revolutionary in 1912. The Funk model of vitamins was of simple amines as essential nutrients, each having a single mode of action in the cure of a specific disease. While vitamins such as thiamine, which is an amine used for curing beriberi, fit this model, others such as vitamin $C$ and $D$ are not amines at all, so there is no ' $E$ ' in the word vitamin. Vitamin $D$ is derived from sunshine, as well as being present in some foods. The vitamin has multiple modes of action, including paracrine, autocrine and endocrine, ${ }^{6}$ with the capacity to affect genes in most tissues of the body. Vitamin $D$ deficiency has been implicated in many diseases. ${ }^{7}$

One anomaly of both conventional and complementary medicine, has been the promotion of vitamin supplementation even when there is no or limited evidence of efficacy. For instance, vitamin $\mathrm{C}$ has been demonstrated to be a cure for scurvy, but not for the common cold. Although Linus Pauling received two Nobel prizes (for Chemistry and Peace), he was more famous for promoting orthomolecular medicine and the use of mega-doses of vitamin $\mathrm{C}$ as cures for cancer ${ }^{8}$ and the common cold, ${ }^{9}$ which have not been substantiated. ${ }^{10,11}$ Another anomaly has been the limited supply of vitamins for life-threatening medically sanctioned diseases, such as thiamine for Wernicke Korsakov syndrome, ${ }^{12}$ while supplies of over-the-counter vitamins remain unrestricted.

Funk's original model of the vitamin with a single mode of action has resulted in scepticism and intense criticism of newer research indicating that vitamins may have multiple actions. An example is vitamin $\mathrm{D}$, which has demonstrated multiple modes of action ${ }^{6}$ and which plays a substantive role in the management of many diseases. ${ }^{13}$

\section{Conclusion}

Dr. Casimir Funk, the "father of the vitamin", initiated substantial advances in the world of nutrients beginning in 1912, and anticipated many other findings in biochemistry, leading to the establishment of the vitamin industry. Funk's legacy was the assertion that vitamins are inherent in food, and that have a single action that is relevant to a specific disease. While it is true that some vitamins are amines, most are not; some are effective for multiple diseases, while one does not come primarily from food.

A century later, we may realise the limitations of Funk's theories, but this does not detract from his genius, or his influence on medical thinking, and the founding of the vitamin industry.

\section{References}

1. Funk C. The etiology of the deficiency diseases. Beriberi, polyneuritis in birds, epidemic dropsy, scurvy, experimental scurvy in animals, infantile scurvy, ship beriberi, pellagra. Journal of State Medicine. 1912; 20: 341.

2. Schneiderman H, I.J. Karpman IJ. Who's Who in World Jewry 1965: A Biographical dictionary of outstanding Jews. New York, NY: McKay; 1965: 417.

3. Griminger P. Biography of Casimir Funk. J. Nutr. 1972; 102 (9):1105-1113.

4. Funk C. Die Vitamine. Cambridge: J.P. Berg; 1914.

5. Congressional Record 112th Congress (2011-2012) Speech of Hon. Frank Pallone, Jr. of New Jersey in the House of Representatives; September 2012; Washington, D.C. Available from: [http://thomas.loc.gov/cgibin/query/z?r112:E21SE2-0247:/]

6. Morris HA, Anderson PH. Autocrine and Paracrine Actions of Vitamin D. Clin Biochem Rev. 2010; 31(4): 129-138. PMCID: PMC2998276

7. Holick MF, Vitamin D deficiency. N Engl J Med. 2007; 357:266-281. doi: 10.1056/NEJMra070553

8. Hoffer LJ. Proof versus plausibility: rules of engagement for the struggle to evaluate alternative cancer therapies CMAJ. 2001; 164(3): 351-353. PMCID: PMC80728

9. Hemilä $H$. Do vitamins $C$ and $E$ affect respiratory infections? PhD dissertation. Helsinki; 2006. [http://ethesis.helsinki.fi/julkaisut/laa/kansa/vk/hemila/] 10. Moertel CG, Fleming TR, Creagan ET, Rubin J, O'Connell MJ, Ames MM. High-dose vitamin C versus placebo in the treatment of patients with advanced cancer who have had no prior chemotherapy: A randomized double-blind comparison. N Engl J Med. 1985 Jan 17;312(3):137-41. 
11. Douglas RM, Hemilä H, Chalker E, Treacy B.

Vitamin $C$ for preventing and treating the common cold. Cochrane Database Syst Rev. 2007 Jul 18;(3):CD000980.

12. Spedding S, Gaughwin MD. Critical shortage of injectable thiamine in Australia. Med J Aust. 2004; 181(10): 577-578.

13. Holick MF. Evidence-based D-bate on health benefits of vitamin D revisited. Dermatoendocrinol. 2012;4(2):183-190. doi: 10.4161/derm.20015 PMCID: PMC3427198

\section{ACKNOWLEDGEMENTS}

The author acknowledges The Pauling Blog for use of the images of $\mathrm{Dr}$ Casimir Funk and Oscodal http://paulingblog.wordpress.com/2011/06/15/casimir-

funk-and-a-century-of-vitamin.

\section{PEER REVIEW}

Not commissioned. Externally peer reviewed.

\section{CONFLICTS OF INTEREST}

The author declares no competing interests 